NBER WORKING PAPER SERIES

\title{
AGGLOMERATION ECONOMIES AND RACE SPECIFIC SPILLOVERS
}

\author{
Elizabeth Ananat \\ Shihe Fu \\ Stephen Ross \\ Working Paper 28847 \\ http://www.nber.org/papers/w28847 \\ NATIONAL BUREAU OF ECONOMIC RESEARCH \\ 1050 Massachusetts Avenue \\ Cambridge, MA 02138 \\ May 2021
}

The authors are grateful for comments from participants at the Labor Market Networks session of the 2013 American Economic Association Meetings, the 2012 Housing-Urban-Labor-Macro Conference at the Federal Reserve Bank of Chicago, 2011 Greater Boston Area Urban and Real Estate Economics Seminar at the Federal Reserve Bank of Boston, and seminars at SERC in the London School of Economics, the CPB Netherlands Bureau for Economic Policy Analysis, Ohio State University, Peking University, and Shanghai University of Finance and Economics. This research was supported by the Center for Real Estate and Urban Economics at the University of Connecticut and the National Natural Science Foundation of China (Basic Scientific Center Project \#71988101). The majority of the analyses presented in this paper were conducted using restricted data at a Census Research Data Center. Opinions and conclusions expressed herein are those of the authors and do not necessarily represent the views of the U.S. Census Bureau. Results have been reviewed to ensure that no confidential information is disclosed. The authors have no competing interests to declare. Some research results in this paper were presented earlier in 2013 NBER Working Paper \#18933. The views expressed herein are those of the authors and do not necessarily reflect the views of the National Bureau of Economic Research.

NBER working papers are circulated for discussion and comment purposes. They have not been peer-reviewed or been subject to the review by the NBER Board of Directors that accompanies official NBER publications.

(C) 2021 by Elizabeth Ananat, Shihe Fu, and Stephen Ross. All rights reserved. Short sections of text, not to exceed two paragraphs, may be quoted without explicit permission provided that full credit, including $\odot$ notice, is given to the source. 
Agglomeration Economies and Race Specific Spillovers

Elizabeth Ananat, Shihe Fu, and Stephen Ross

NBER Working Paper No. 28847

May 2021

JEL No. J15,J24,L11,R12,R23,R32

\begin{abstract}
$\underline{\text { ABSTRACT }}$
Racial social isolation within and across workplaces may reduce firm productivity. We provide descriptive evidence that African-Americans feel socially isolated from Whites. To test whether isolation affects productivity, we estimate models of Total Factor Productivity for manufacturing firms allowing returns to local area concentrations of economic activity and human capital spillovers to vary with the racial and ethnic composition of both the establishment and the local area employment. Higher own-race exposure for establishment workers to workers at surrounding establishments strengthens the relationship between productivity and both employment density and concentrations of college educated workers. Effects for human capital spillovers are largest for firms with more patents and more research and development spending. Looming demographic changes suggest that this drag on productivity may increase over time.
\end{abstract}

Elizabeth Ananat

Barnard College

Columbia University

3009 Broadway

Office 1019 Milstein Building

New York, NY 10027

and NBER

eananat@barnard.edu

Shihe Fu

Wang Yanan Institute for Studies

in Economics (WISE)

Xiamen University

Xiamen, 361005

China

fushihe@xmu.edu.cn
Stephen Ross

Department of Economics

University of Connecticut

341 Mansfield Road, Unit 1063

Storrs, CT 06269-1063

and NBER

stephen.1.ross@uconn.edu 


\section{Agglomeration Economies and Race Specific Spillovers}

\section{Introduction}

Many studies document the role of knowledge spillovers as a key factor in explaining firm productivity in cities. Moretti (2004) finds that knowledge spillovers in U.S. cities increase the productivity of manufacturing plants. Glaeser and Maré (2001) and De la Roca and Puga (2017) find that learning plays an important role in explaining the urban wage premium. Ellison, Glaeser and Kerr (2010) find evidence that spillovers between firms explain a significant portion of the coagglomeration of industries using metrics for the extent that firms share workers and ideas. Rosenthal and Strange (2008), using wages, and Rosenthal and Strange (2003), examining firm births, document a fairly rapid decay of spillovers across space, consistent with agglomeration resulting from social interactions. Similarly, Audretsch and Feldman (1996) and Feldman and Audretsch (1999) demonstrate that the composition of surrounding industry affects the rate of new ideas as captured by product innovation. ${ }^{1}$

Racial and ethnic isolation and racially segregated networks among workers appear to be important drivers of differences in labor market outcomes, especially for African-Americans. Hellerstein et al. (2008) find that an African-American's own employment depends not on nearby overall employment density, but rather on whether nearby employers employ other AfricanAmericans. Hellerstein et al. (2011) find that workers are more likely to be employed at a firm that contains other workers residing in the same neighborhood, but document that these network effects are substantially stronger for African-Americans and Hispanics if those workers are the same race/ethnicity. ${ }^{2}$ Ananat, Fu and Ross (2018) demonstrate that the wage premium arising from

\footnotetext{
${ }^{1}$ See Combes and Gobillon (2015) for a recent review.

2 Bayer et al. (2008) also documents labor market network effects based on residential proximity of similar workers. Ioannides and Loury (2004) and Ross (2011) review the referral literature.
} 
working in a location with high employment density is substantially smaller for AfricanAmericans, unless the surrounding employment is comprised predominantly of African-American workers.

Even when Blacks are in spatial proximity with other races, research has shown they remain socially isolated from non-Blacks. For example, Davis et al. (2019) document racial segregation in visits to restaurants and find that most of this segregation is due to social barriers and, moreover, is strongest in isolating African-American diners and restaurants. Similarly, many studies document racial isolation within schools (Fletcher et al. 2020; Moody 2001), particularly for Black students (Echinique and Fryer, 2005).

Given the patterns observed above, racial and ethnic social isolation between workers sharing workplaces or in neighboring workplaces may have a significant impact on firm productivity, a possibility we investigate in this study. First, we utilize the General Social Survey (GSS) to provide descriptive evidence that African-Americans do in fact feel socially isolated from Whites, including when working at majority White firms. Specifically, white respondents are 1.6 points in terms of feeling closer to whites than they feel to blacks on a 9 point Likert scale, and black respondents are 1.7 points closer to blacks than to whites. Further, we find no evidence that this 3.3 point closeness gap falls as the share of whites in the workplace increases. ${ }^{3}$

Second, we test whether this social isolation of African-American workers affects firm productivity. We estimate models of Total Factor Productivity (TFP) for manufacturing firms in which we allow the returns to concentrated economic activity and human capital spillovers to vary by each establishment's racial and ethnic composition in a way that depends upon the racial and ethnic composition of employment in the surrounding area. Specifically, consistent with individual

\footnotetext{
${ }^{3}$ While perhaps intuitive, this pattern has not to our knowledge been shown in previous work. Unfortunately, the GSS does not collect similar information for Asians, Hispanics, or other race/ethnic groups.
} 
employees' race-specific networks mattering for productivity, we find that manufacturing establishments whose workers on average are exposed to a higher share of manufacturing workers of the same race in the local work area experience a stronger relationship between productivity and both local area employment density and share of workers with four years of college.

Following Moretti (2004) and Hellerstein et al. (1999), we identify a sample of workers in each manufacturing establishment from the 2000 Decennial Census Long Form data based on that establishment's zip code and three-digit NAICS (industry) code, and then estimate the education and racial composition of the workers in each zip code by industry establishment cell. ${ }^{4}$ We then estimate a standard translog production function with measures of each establishment's various capital and labor inputs along with controls for the density and education of workers in this establishment's nearby peers (defined as other manufacturing firms in the surrounding U.S. Census Public Use Microdata Area, or PUMA). We then calculate the average exposure of the establishment's workers to establishment workers of their own race/ethnicity in this PUMA and allow the establishment's productivity returns to employment density and returns to the share of workers in the PUMA who are college-educated to vary with this same-race exposure. Our preferred estimates, in which the model includes a proxy for unobserved worker ability based on Fu and Ross (2013), suggests that the estimated effects of employment density and share of employees who are college graduates (share college) on productivity both fall to near zero for establishments whose workers have no exposure to same-race workers in the PUMA.

Our model and robustness checks attempt to address many of the common concerns in empirical work on agglomeration and human capital externalities. Ciccone and Peri (2006) note

\footnotetext{
${ }^{4}$ While Moretti (2004) and Hellerstein et al. (1999) match establishments based on metropolitan area, we match based on zip code and similar to Rosenthal and Strange (2003, 2008), Fu and Ross (2013) and Ananat et al. (2018) examine variation within metropolitan areas.
} 
that the educational composition of workers in a given location can affect local wages due to input complementarities and substitutability, rather than production spillovers. A significant advantage of our use of TFP models is explicitly allowing for substitution between inputs. Another concern is that workers may sort into high-density work locations based on their unobserved productivity (Glaeser and Maré 2001; Combes et al. 2008). To address this, we estimate a wage equation with fixed effects for residential location at the census tract level. We then use the average of these fixed effects over the residential location of workers at an establishment as a proxy for establishment-level unobserved worker productivity, leveraging previous findings that workers sort over residential locations based on permanent income (Bayer and Ross 2006; Fu and Ross 2013). Our results are also robust to allowing the effects of employment density and share college within PUMAs to be heterogeneous across NAICS industry categories, as well as to allowing for innate differences in place-specific productivity by including fixed effects for each establishment's PUMA. Moreover, we also find that same-race exposure effects on the return to share college, which may reflect human capital externalities or knowledge spillovers, are concentrated in industries with higher levels of patent activity and research and development spending, suggesting that racial isolation within firms may also influence firm operation and innovation. ${ }^{5}$

\section{Are Black workers socially isolated from Whites, even when they work in predominantly}

\section{White firms?}

First, we examine whether self-reported patterns of individual associations within and across race/ethnicity are consistent with the hypothesis that social ties are disproportionately within-race and that those workers whose workplaces include few or no same-race peers are unable to

\footnotetext{
${ }^{5}$ This is consistent with several previous studies that document the role of peers and social interactions within companies. For example, Nanda and Sorenson (2010) find evidence of peer effects on self-employment that suggests knowledge- or experience-sharing between workers. Other work suggests that peers may affect productivity through establishing productivity-enhancing norms (De Paola 2010; Bandiera et al. 2005; Mas and Moretti 2009).
} 
overcome this pattern. To test whether Blacks in majority-White workplaces nonetheless report greater social distance from Whites than from Blacks, and vice versa, i.e. that race is a barrier to social interactions in the workplace, we draw on data from the U.S. General Social Survey. This survey has been fielded every one or two years since 1972 and contains a standardized set of demographic and attitudinal questions, many of which are asked consistently over time. A substantial number of respondents across a number of waves are surveyed on: racial attitudes; the racial composition of their workplace; ${ }^{6}$ and how close they feel to Blacks and to Whites. We focus on Black and White respondents, as the survey did not ask comparable questions on closeness and workplace composition concerning Hispanics, Asian-Americans, or other race or ethnicity workers. Our sample includes employed Blacks and Whites who responded to the surveys in which the relevant questions were asked.

Survey respondents' workplaces are on average $68 \%$ White, and the racial distributions of firms employing Blacks and Whites are heavily overlapping: the average White employee worked in a $72 \%$ White workplace and the average Black employee worked in a 50\% White workplace, with standard deviations of around $37 \%$ for both groups. Thus, there is plenty of variation within which to test the relationship between feelings of closeness across race and workplace racial composition, for both Blacks and Whites.

Our main focus is on a pair of personal attitude questions about how close the respondent is to Whites and how close the respondent is to Blacks, reported on a Likert scale running from 1 to 9 where 1 is not close at all and 9 is very close. ${ }^{7}$ Columns 1 and 2 of Table 1 Panel 1 show the mean

\footnotetext{
${ }^{6}$ These responses could reflect the worker's establishment or their more immediate office environment, but would not reflect the overall firm in the case of multi-establishment firms.

${ }^{7}$ Race, closeness to Whites and Blacks, and attitude toward government help for Blacks were asked in all years of the survey. Workplace racial composition was surveyed in 1990 and biannually (i.e., in every survey) between 1996 and 2010. The exception is attitudes toward interracial marriage, which was discontinued as a question in 2002. The regression samples include all employed Whites and Blacks who responded to the specific racial attitude question. If workplace share white is missing, the variable is set to zero, and an indicator for the variable missing is set to one.
} 
levels of closeness to Blacks and Whites respectively. Not surprisingly, both Black and White workers report being closer to their own race than to the other race: Blacks report being 2.2 points on a 9-point scale closer to Blacks than do Whites (rows 1 and 2 column 1), while Whites report being 1.1 points closer to Whites than do Blacks (rows 1 and 2 column 2). Column 3 shows the estimates for difference between a worker's closeness to Whites and closeness to Blacks, which we view as a likely proxy for the racial composition of meaningful social interactions and treat as our main metric. Blacks on average report feeling 1.7 points closer to Blacks than to Whites, while Whites report feeling 1.6 points closer to Whites than to Blacks, an illustration of the high levels of social distance between races in American society. Columns 4 and 5 of Table 1 report two additional race-related attitudinal survey measures: whether the government provides too much assistance to Blacks and support for interracial marriage. Whites are more likely to agree with the first statement on government assistance, and less likely to support interracial marriage, than are Blacks.

These high levels of average social distance, however, would mean little for race-specific spillovers at work if they merely reflected low average levels of interaction between races due to segregation across work locations, while disappearing for workers with high levels of cross-race exposure in the workplace. If that were the case, we would see that a worker's relative closeness to a group would increase with the representation of that group in their workplace, so that, for example, a Black worker in an all-White firm would report on average the same closeness to Whites as would a White worker in an all-White firm. Therefore, we estimate models to explain these variables that include an indicator for own race, a measure of the percent White in workplace, and an interaction of the two; the model also includes the indicators for survey year. ${ }^{8}$

\footnotetext{
${ }^{8}$ We have also estimated this set of regressions with fixed effects for MSA; standard errors increase but neither coefficients nor the pattern of significance changes.
} 
Table 1 Panel 2 and Figure 1 report results. As percent White in the workplace increases, Whites become substantially less close to Blacks (column 1) and minimally closer to Whites (column 2). The interaction of Black with percent White in workplace implies that closeness of Blacks to Blacks decreases modestly at most, but closeness to Whites does increase with percent White. Turning to column 3, the net effect on relative closeness is that both groups increase their closeness to Whites relative to Blacks as percent White increases, but the point estimates on the interaction between Black and percent White implies that the effect for Whites is more than 50\% larger than the effect for Blacks. While the interaction estimate is somewhat noisy, the negative sign implies that increasing percent White in the workplace does not mitigate the large gap between Whites and Blacks in terms of their relative closeness to Whites.

Figure 1 graphs the estimated relationship between firm racial composition and closeness to Whites relative to Blacks separately for Whites and for Blacks. We observe a large gap of over two Likert scale points in an all-Black workplace, where lower relative closeness to Whites might be an advantage, but this large gap persists and may even grow as the percent White in the work place increases. As a result, White workers may have a significant advantage in communication opportunities within workplaces that contain primarily White workers. Finally, the estimates in columns 4 and 5 in the second panel of Table 1 imply that unlike closeness to Whites and Blacks, an increase in the share White in the workplace has no impact on more general racial attitudes like support for government programs that are perceived as utilized heavily by Blacks or support for interracial marriage. 


\section{Do Racially-Segregated Networks Affect Productivity?}

\subsection{Methods}

Next, we test whether the apparent racial segregation of social networks affects firm productivity by using establishment exposure to agglomeration economies and human capital spillovers as a shifter of firm productivity. We model establishment Total Factor Productivity (TFP) as a function of spatial spillovers that depends upon both firm demographics and local labor market area demographics. Specifically, we estimate models for the logarithm of establishment net revenue ( $N_{i j}$, total revenues minus material costs) as a translog function, given Ciccone and Peri's (2006) concerns about factor substitution. The translog function includes establishment structure capital, equipment capital, and following Moretti’s (2004) analysis of human capital externalities also includes separate estimates of college-educated and non-college educated employment $\left(X_{i j}\right)$. We then again follow Moretti (2004) and include linear controls for our variables that may drive spillovers: manufacturing employment density and share manufacturing workers with four years of college, for a sub-region of the metropolitan or labor market area surrounding the establishment $\left(Z_{j}^{-i}\right)$.

$$
N_{i j}=F\left(X_{i j}\right)+\beta Z_{j}^{-i}+\varepsilon_{i j}
$$

where $F$ is a quadratic additive function of all elements of $X_{i j}$ including all two-way interactions.

The $-i$ in $Z_{j}^{-i}$ represents the omission of the establishment itself and same industry establishments from the calculation of $Z$ following Moretti (2004). ${ }^{9}$ Moretti (2004) argues that it is impossible to

\footnotetext{
${ }^{9}$ Guryan et al (2009) and Bayer et al. (2008) show that omission of self or a cluster of related observations can bias estimates of peer effects. Fletcher et al. (2020) generalize Guryan et al.'s solution to this bias to a broader set of calculated variables where the control function is the difference between the variable calculated using all data and the variable omitting a cluster of the data. We calculate this Guryan style control function for our employment density and share college educated variables and include these in the TFP models. All results are robust to the omission of these controls.
} 
estimate spillovers within establishments from the same industry with establishment data as used by him and ourselves, likely due to reflection problems that might arise in estimating effects of own industry for many firms in the same industry that all contribute to each other's measures of agglomeration. ${ }^{10}$ All models also include metropolitan/labor market area fixed effects and industry fixed effects.

Next, for the surrounding sub-region or local area, we also calculate a measure intended to capture race-specific opportunities for communication and the transfer of information between workers at nearby establishments. If information transfer occurs at the individual worker level, then the returns to agglomeration and human capital externalities should depend upon the individual employees’ opportunities for social interactions with workers at nearby firms. In order to capture that, we measure each employee's exposure to workers of neighboring establishments who are also of the same race $\left(\theta_{r j}^{-i}\right)$ based on their race $r$ and their establishment's location $j$, and then calculate the average of this exposure across all workers at each establishment $i$.

$$
E_{i j}=\sum_{r} W_{r i j} \theta_{r j}^{-i}
$$

where $W_{r i j}$ is the share of workers in the establishment belonging to a specific racial category.

A larger value of this racial exposure index suggests workers of the dominant race/ethnicity in an establishment are more heavily exposed to same-race peers in other establishments in the same sub-region. We calculate a similar measure for exposure of workers to college-educated workers of the same race in this local area.

We then interact these two variables with the employment density and share collegeeducated, respectively, to test whether returns to employment density and share college in terms

\footnotetext{
${ }^{10}$ For example, unobserved place attributes may attract many firms in the same industry even without spillovers. This issue represents a common concern in empirical estimates of agglomeration economies, motivating for example Rosenthal and Strange’s (2003) focus on establishment births and Ellison et al.’s (2010) focus on co-agglomeration.
} 
of firm productivity depend upon establishment employees' interaction opportunities with samerace workers in other establishments.

$$
N_{i j}=F\left(X_{i j}\right)+\beta Z_{j}^{-i}+Z_{j}^{-i \prime} \Omega E_{i j}+\gamma E_{i j}+\delta W_{i j}+\varepsilon_{i j},
$$

where $E_{i j}$ is a vector containing the two exposure variables, and $\Omega$ is a diagonal matrix containing the parameters for the two interaction terms. The models also include a vector of controls capturing the racial composition of establishment employment $\left(W_{i j}\right)$.

\subsection{Data}

Our TFP models are estimated using a combination of confidential datasets based on the Long Form of the 2000 U.S. Decennial Census and the Longitudinal Business Database (LBD). The confidential long-form sample provides detailed geographic information on individual residential and work location down to the census block level, and the LBD identifies the zip code of every establishment. We restrict ourselves to manufacturing establishments that participate in the 2002 Annual Survey of Manufacturers, and merge in data on estimated establishment capital stock (Foster, Grim, and Haltiwanger 2016). ${ }^{11}$ For each establishment, we observe revenue, materials cost, number of employees, estimated capital stock of structures, and estimated capital stock of equipment in 2002. We further restrict our sample to the 49 Consolidated Metropolitan and Metropolitan Statistical Areas with populations over 1 million.

Starting with our sample of establishments in large metropolitan areas, we link information from the census long form following Moretti (2004) and Hellerstein et al. (1999). First, we assign establishments into zip code by three-digit industry NAICS code cells to represent an "establishment". We then use the census block of work matched to the zip code and industry of

\footnotetext{
${ }^{11}$ We thank Cheryl Grim at the US Census Bureau for both providing this data and providing advice in terms of its application.
} 
employment from the decennial census data to calculate the fraction of workers in each cell who have four-years of college or more. This college educated share is multiplied by establishment total employment to estimate the number of college-educated workers, and one minus this share is multiplied by employment to estimate the number of non-college educated workers. ${ }^{12}$ We use the same strategy to calculate the fraction of workers who are non-Hispanic White, non-Hispanic African-American, Non-Hispanic Asian or Pacific Islander, and Hispanic for each “establishment”.

Then, we use the census defined residential Public Use Microdata Areas (PUMAs), which are geographically contiguous areas that contain a population of 100,000 residents or more, as our definition of local labor market areas within each metropolitan area. Residential PUMAs provide us with a local area that is larger than zip code, since we use zip code to define three digit industry establishment clusters for merging data on worker education and race, and yet still small enough to allow a minimum of 10 PUMA's in each metropolitan area in our sample. ${ }^{13}$ We then merge establishments into the residential PUMAs and use the long form decennial census data to calculate employment density and share of employees with four years of college based on manufacturing workers in each PUMA, omitting the employment associated with an establishment's own three digit NAICS code industry. We also calculate the fraction of manufacturing workers who are nonHispanic White, non-Hispanic African American, non-Hispanic Asian or Pacific Islander, and Hispanic in each PUMA in this case omitting the employment in the establishment zip code by

\footnotetext{
${ }^{12}$ In cases for which we cannot match to an establishment zip code, we base our estimates on industry-PUMA cells. ${ }^{13}$ The census also defines workplace PUMAs, but these areas are very uneven in size across states and often much larger than residential PUMAs, sometimes encompassing entire central cities.
} 
three digit industry cell since we are trying to capture establishment employee interactions with employees of other establishments in the PUMA. ${ }^{14}$

As noted above, we use the decennial Census data to calculate: 1 . the share of the workforce at each establishment $i$ that is White, Black, Hispanic, or Asian-American $\left(W_{\text {rij }}\right)$ based on the establishment's industry-zip code cell, and 2. the share of the manufacturing workforce in each PUMA $j$ that is of a given race $r$ omitting the employment associated with the establishment cell $\left(\theta_{r j}^{-i}\right)$. Using these shares and aggregating individual own race exposure $\left(\theta_{r j}^{-i}\right)$ across all employees in an establishment cell, see equation (2) above, we calculate the average exposure of workers in an establishment to manufacturing workers of the same race in the establishment's PUMA. We calculate a similar measure for exposure of workers in an industry-zip code cell to college-educated workers of the same race in this PUMA, again omitting college educated workers from the zip code- three digit industry cell, where share of college educated manufacturing workers of a given race is relative to all college-educated manufacturing employment. As discussed above, we then interact these two variables with the PUMA-manufacturing employment density and the PUMAmanufacturing share college-educated, respectively. We also include direct controls for the estimated racial composition of the workers in each establishment (i.e. industry-zip code cell).

The summary statistics of all variables are presented in Table 2.

\subsection{Results}

The results of our initial translog model in equation (1) are shown in Column 1 of Table $2 .{ }^{15}$ We estimate the conditional correlation between establishment productivity and employment density finding that a one-standard-deviation increase in employment density ( $\mathrm{SD}=1.032)$ and in

\footnotetext{
${ }^{14}$ We first match each plant in the 2002 Census of Manufacturing firms with a plant in the Standard Statistical Establishment List (SSEL) data by plant ID. The SSEL data are used to assign a PUMA ID to each plant through the census tract-PUMA cross-reference file.

${ }^{15}$ A full set of estimates for the first three columns of Table 2 are shown in Appendix Table A1.
} 
share college ( $\mathrm{SD}=0.1060)$ in a local work area PUMA are associated with 0.030 and $0.022 \log$ points increase in net revenue, respectively. The share college estimate is comparable in magnitude to Moretti's cross-MSA estimates of between 0.035 and 0.049 for human capital externality spillovers for a one standard deviation increase in share college in an MSA, especially considering that our estimate is reduced substantially by the inclusion of the control for employment density, which was not included in Moretti's model. All models control for three digit industry and MSA fixed effects, and standard errors are clustered at the PUMA level.

We next estimate equation (3), which includes the interactions of agglomeration and share college with the establishment's average own race exposure of workers. These results are shown in column 2 of Table 3. We find a strong, statistically significant estimate on the interaction between employment density and workers' average exposure to own-race manufacturing workers in the PUMA (row 2). A one standard deviation increase in exposure to own race or ethnicity workers $(S D=0.207)$ implies an increase in the effect of employment density of 0.019 , relative to a baseline effect of employment density (column 1 row 1) of 0.029. In fact, our estimates suggest that there is no relationship between productivity and employment density for an establishment whose workers have no exposure to same-race workers in the PUMA. In other words, increased density of employment is associated with increases in establishment's productivity, but likely only if the increased density comes from an increase in workers of the same race as that establishment's workers. A zero return to density for non-White firms in predominantly White local work areas is consistent with the GSS results showing significant relative social isolation of Black workers from Whites even in all-White workplaces.

The estimated interaction between firm average exposure to same-race college-educated workers and share college-educated workers in a PUMA (row 4), while not quite statistically 
significant in column 2 (p-value=.11), is in the expected direction and sizable, with nearly the same magnitude as the estimate in column 1 of the direct estimate on share college-educated in the PUMA. While noisily estimated, the standardized effect of exposure to own race college educated workers is 0.041 , relative to a baseline effect (column 1 row 3 ) of 0.203 . The direct effect of share college falls from 0.20 to 0.10 with the inclusion of the interaction term. An establishment with zero exposure to college-educated workers in the PUMA who are the same race as its own workers is estimated to have an association between productivity and college-educated workers in the PUMA that is one-half the magnitude of the relationship for the average establishment, according to the point estimates.

A common concern in the agglomeration literature is that workers may sort across firms or locations based on the unobserved attributes of either the firms or the locations. Unlike acrossmetropolitan areas studies (Glaeser and Maré 2001; Combes et al. 2008), Fu and Ross (2013) and Ananat et al. (2018) document that the within-metropolitan area, across-local work area correlations of employment density with both observable worker human capital and worker race are near zero. However, these studies suggest that workers may sort over education levels of work locations based on individual education. Therefore, following Fu and Ross (2013), we use the decennial census data to estimate a wage model for prime-age, full-time male workers in our large metropolitan areas that includes controls for residential census tract fixed effects as a proxy for the unobserved human capital of workers, as well as a standard set of individual demographic variables. ${ }^{16}$ If workers sort across residential locations based on permanent income, these fixed effects may act as a partial control function for the unobserved productivity of workers (Bayer and

\footnotetext{
${ }^{16}$ Prime-age workers are defined as 30-59 years of age, and full time is defined as usual hours worked per week 35 or greater. Wages are calculated as last year's earnings divided by the product of number of weeks worked last year and usual hours worked per week. Our demographic controls include categorical variables by race and ethnicity, age, education, family structure, and immigration status. See Ananat et al. (2018) for additional details.
} 
Ross 2006; Fu and Ross 2013). For each establishment, we calculate a proxy for unobserved human capital by averaging the estimated census tract fixed effects from the wage regression over the residential location of the workers matched to each three-digit industry by zip code establishment cell. ${ }^{17}$ This measure of worker human capital is then included in the translog production function as a fifth input.

In column 3, we present our results after including this new control for the unobserved human capital of workers at each establishment. ${ }^{18}$ The effect of the within-PUMA, own race exposure of an establishment's workers on the return to density is very stable to the inclusion of controls for worker human capital, as expected given the low correlation between employment density and both worker race and education. Therefore, while establishment TFP depends strongly on the unobserved productivity of the establishment's workers, we find no evidence that workers are sorting based on those attributes over employment density. However, the relationship between an establishment's worker's own race match on return to share college increases by 19 percent and is statistically significant after the inclusion of this control for worker unobserved productivity, suggesting that, if anything, the omission of worker unobservables biases these estimates downwards. As a result, the estimated return to share college for an establishment with zero samerace exposure is now only 12 percent of the original estimated return to share college in column 1.

Column 4 of Table 3 presents robustness checks for the final model in Column 3 by adding PUMA fixed effects as well as controls for three-digit industry dummy variables interacted with PUMA employment density and share college. The PUMA fixed effects control non-

\footnotetext{
${ }^{17}$ The residential fixed effects have substantial explanatory power eroding the return to educational attainment in wage regressions by about 25\% (Fu and Ross 2013) and the Black-White wage gap by half (Ananat et al. 2018).

${ }^{18}$ In order to illustrate the effect of the mean tract FE on firm TFP, we also estimated the Cobb-Douglas model with this control and find that the mean tract FE variable has a strong positive effect on TFP with standardized effect size of $0.017 \log$ points and a t-statistic of 3.23.
} 
parametrically for any general relationship between establishment location and TFP arising from location-specific productivity differences or correlated productivity shocks within locations. The three-digit-industry interactions allow the returns to employment density and share college to vary across different types of manufacturing industries, since establishments in different industries likely differ in their innate productivity attributes. These changes greatly increase both the magnitude and the precision of the estimates on the employment density and share college interactions with own race exposure, doubling the own race effect for the returns to employment density and increasing the own race effect for share college by two and one-half times. The inclusion of the PUMA fixed effects to control for location-specific productivity is entirely responsible for the increases in the interaction estimate magnitudes.

In order to consider normative effects on workers, we also examine in Table 4 the impact of exposure to own-race or own-ethnicity workers on the productivity of firms at which non-White workers are employed, essentially measuring racial differences in worker exposure to establishment productivity. Since Whites are the majority and tend to work at majority White establishments, White workers tend to have a relatively high exposure to establishments who on average have workers with high exposure to other own race workers within the establishment's PUMA. White workers' average exposure (over all establishment workers) within work location is 0.634 (column 1), while the exposures for African-American, Hispanic and Asian workers are lower at $0.487,0.407$ and 0.406 , respectively (column 2). ${ }^{19}$ Multiplying the estimated coefficient of 0.0913 (column 4) from column 3 of Table 3 by the mean employment density for the establishment sample of 0.307 (column 3) implies a lower bound Black-White gap in exposure to establishment productivity of 0.4 percentage points $((0.635-0.487) * 0.0913 * 0.307)$, while the

\footnotetext{
${ }^{19}$ The average exposure rates are calculated by estimating the mean exposure index across establishments weighted by the number of estimated workers of each race at each establishment.
} 
larger coefficient from column 4 of Table 3 after controlling for PUMA fixed effects and differential returns by three-digit industry implies an upper bound contribution of 0.8 percentage points. Further, the exposure gaps for Hispanics and Asian workers are 50 percent larger than the Black-White gap. These results are summarized in Panel 1 of Table 4. Similarly, the White, African-American, Hispanic, and Asian worker exposures to their establishment's worker's ownrace match for college-educated workers are $0.665,0.499,0.376$ and 0.419 , respectively, and using the estimates from column 3 of Table 3 these differences imply productivity exposure differences of 0.9 percentage points, with gaps for Hispanics and Asians being 70 and 50 percent larger, respectively. See Panel 2 of Table 4.

If the hypothesis that information spillovers are segregated within same-race networks holds, then high worker exposure to workers at surrounding establishments of the same race should matter more for productivity in industries that rely on innovation and high-intensity social interactions. We test this implication in Columns 2 through 5 of Table 4. Starting with column 3 of Table 2 as our baseline model (column 1 repeats these results), we show results for subsamples split by how much establishments rely on innovation, i.e. whether the three-digit industry has a high vs. low rate of patent production or has high versus low R\&D spending. ${ }^{20}$ For both patent activity and R\&D spending, share college/human capital externality effects are significantly higher in the high-patent/high R\&D spending industries than in the below median industries. Results are less clear for employment density with larger agglomeration effects in low patent industries and similar estimates over R\&D spending.

\footnotetext{
${ }^{20}$ We are grateful to William Kerr at the Harvard Business School for providing this data (Kerr 2008).
} 


\section{Discussion}

In this paper, we examine the role of race and ethnicity in shaping the productivity spillovers experienced by manufacturing firms operating within large metropolitan areas. First, we use the General Social Survey to document communication barriers between Whites and Blacks, finding that the racial differences in the social distance that Black workers report with respect to Whites persists even among Blacks who work in all-White firms. These results suggest that Blacks experience relatively little access to White workplace networks. Next, we use confidential establishment data to estimate a model of firm total factor productivity for a sample of manufacturing establishments, and we find strong evidence that the productivity returns to local employment density and share college rise as the average exposure of workers in a firm to samerace peers in the local work area or PUMA rises. These spillovers are quite low or even zero for firms whose employees lack same-race peers at surrounding firms. Further, for human capital externalities, same-race exposure matters even more in patent-intensive and $R \& D$ spending industries.

These findings are consistent with the idea that limited social interactions between workers across race or ethnicity may have negative impacts on the overall productivity of manufacturing firms and innovation in the manufacturing sector, as well as particularly large negative impacts on majority non-White firms. We cannot distinguish whether these differences in spillovers arise from implicit barriers to interracial social interactions or from working conditions and other institutional barriers to communication. Our approach is unable to answer the question of whether this differential exposure to establishment productivity leads to welfare differences between Blacks and Whites, but evidence in Fu and Ross (2013) and Ananat et al (2018) imply that Black workers experience lower wage returns than do Whites from exposure to higher levels of agglomeration. 
It is also worth noting, however, that the lower firm productivity among firms that have a worse racial and ethnic match with the local employment area may also be harmful to the wages and productivity of Whites, as it reduces the effective size of the agglomeration from which they can benefit. ${ }^{21}$ It is less harmful to Whites than to minorities merely because Whites currently make up the majority of most manufacturing employment. Looming demographic changes suggest, therefore, that social distance between races could become more of a drag on productivity for Whites, and for the economy overall, going forward, unless proactive steps are taken to reduce racial and ethnic isolation. Our results suggest that this holds in particular for high-innovation industries expected to drive the nation's economic growth. Our findings thus provide additional motivation for policies to improve race relations and increase interracial contact.

\footnotetext{
${ }^{21}$ It is also possible that White workers benefit from this phenomenon if the increased concentration of social interactions with the members of a worker's own race leads to interactions for Whites with individuals who on average are more skilled and have more advanced knowledge to share. See Logan and Zhang (2013) and De la Roca, Ellen, and O’Regan (2014) for examples of evidence that Whites may benefit from segregation.
} 


\section{References}

Ananat, Elizabeth, Shihe Fu, Stephen L. Ross, 2018. Race-specific Urban Wage Premia and the Black-White Wage Gap. Journal of Urban Economics 108, 141-153.

Audretsch, David B. and Feldman, Maryann P. 1996. R\&D Spillovers and the Geography of Innovation and Production. American Economic Review, 86, 630-640.

Bandiera, Oriana, Iwan Barankay and Imran Rasul. 2005. Social Preferences and the Response to Incentives: Evidence from Personnel Data. Quarterly Journal of Economics 120(3): 917-62.

Bayer, Patrick, and Stephen L. Ross. 2006. Identifying Individual and Group Effects in the Presence of Sorting: a Neighborhood Effects Application. Working Paper no. 12211, National Bureau of Economic Research, Cambridge, MA.

Bayer, Patrick, Stephen L. Ross, and Giorgio Topa. 2008. Place of Work and Place of Residence: Informal Hiring Networks and Labor Market Outcomes. Journal of Political Economy 116: 1150-96.

Ciccone, Antonio and Giovanni Peri. 2006. Identifying Human-Capital Externalities: Theory with Applications. The Review of Economic Studies 73(2): 381-412.

Combes, Pierre-Philipi, Gilles Duranton, and Laurent Gobillon. 2008. Spatial Wage Disparities: Sorting Matters! Journal of Urban Economics 63: 723-42.

Combes, Pierre-Philippe and Laurent Gobillon. 2015. The Empirics of Agglomeration Economics. In The Handbook of Urban and Regional Economics Vol 5 (G. Duranton, V. Henderson, W. Strange). Elsevier BV.

De la Roca, Jorge, Ingrid Gould Ellen, and Katherine M. O’Regan. 2014. Race and Neighborhoods in the 21st Century: What does Segregation Mean Today? Regional Science and Urban Economics 47:138-151. 
De la Roca, Jorge and Diego Puga. 2017. Learning by working in big cities. Review of Economic Studies 84(1): 106-142.

De Paola, Maria. 2010. Absenteeism and Peer Interaction Effects: Evidence from an Italian Public Institute. Journal of Behavioral and Experimental Economics 39(3): 420-28.

Davis, Donald R., Jonathan I. Dingel, Joan Monras and Eduardo Morales. 2019. How Segregated is Urban Consumption? Journal of Political Economy 127(4): 1684-1738.

Echinique, Federico and Roland G. Fryer, 2005. On the Measurement of Segregation. NBER Working Paper \#11258.

Ellison, Glen, Edward Glaeser, and William Kerr. 2010. What Causes Industry Agglomeration? Evidence from Coagglomeration Patterns. American Economic Review 100: 1195-213.

Feldman, Maryann P. and David B. Audretsch. 1999. Innovation in Cities: Science-based Diversity, Specialization, and Localized Competition. European Economic Review 43: 40929.

Fletcher, Jason, Stephen L. Ross and Yuxiu Zhang. 2020. The Determinants and Consequences of Friendship Composition. Journal of Urban Economics 116: \#103241.

Foster, Lucia, Cheryl Grim and John Haltiwanger. 2016. Reallocation in the Great Recession: Cleansing or Not? Journal of Labor Economics 34(S1): S293-S331.

Fu, Shihe and Stephen L. Ross. 2013. Wage Premia in Employment Clusters: How Important is Worker Heterogeneity? Journal of Labor Economics 21: 271-304.

Glaeser, Edward L. and David C Maré. 2001. Cities and Skills. Journal of Labor Economics, 19 : $316-42$. 
Guryan, Jonathan, Kory Kroft and Matt Notowidigdo. 2009. Peer effects in the workplace: Evidence from random groupings in professional golf tournaments. American Economic Journal: Applied Economics 1(4): 34-68.

Hellerstein, Judith K., Melissa McInerney, and David Neumark. 2011. Neighbors and CoWorkers: The Importance of Residential Labor Market Networks. Journal of Labor Economics 29(4): 659-95.

Hellerstein, Judith K., David Neumark, and Melissa McInerney. 2008. Spatial Mismatch or Racial Mismatch. Journal of Urban Economics 64: 464-69.

Hellerstein, Judith K., David Neumark, and Kenneth R. Troske. 1999. Wages, Productivity, and Worker Characteristics: Evidence from Plant Level Production Functions and Wages Equations. Journal of Labor Economics 17: 209-47.

Ioannides, Yannis M. and Linda Datcher Loury. 2004. Job Information Networks, Neighborhood Effects, and Inequality. Journal of Economic Literature 42: 1056-93.

Kerr, William R. 2008. Ethnic Scientific Communities and International Technology Diffusion. The Review of Economics and Statistics 90: 518-37.

Logan, John R. and Weiwei Zhang. 2013. Separate but Equal: Asian Nationalities in the U.S. Report, US2010 Project.

Mas, Alexandre and Enrico Moretti 2009. Peers at Work. American Economic Review 99(1): 11245.

Moody, James. 2001. Race, School Integration, and Friendship Segregation in America. American Journal of Sociology 107(3): 679-716.

Moretti, Enrico. 2004. Workers' Education, Spillovers, and Productivity: Evidence from Plant Level Production Functions. American Economic Review 94: 656-90. 
Nanda, Ramana and Jesper B. Sorenson. 2010. Workplace Peers and Entrepreneurship. Management Science 56: 1116-26.

Rosenthal, Stuart and William Strange. 2008. The Attenuation of Human Capital Spillovers. Journal of Urban Economics, 64(2): 373-89.

Rosenthal, Stuart and William Strange. 2003. Geography, Industrial Organization, and Agglomeration. Review of Economics and Statistics, 85: 377-93.

Ross, Stephen L. 2011. Social Interactions Within Cities: Neighborhood Environments and Peer Relationships. In Handbook of Urban Economics and Planning (Eds. N. Brooks, K. Donaghy, G. Knapp). Oxford University Press. 


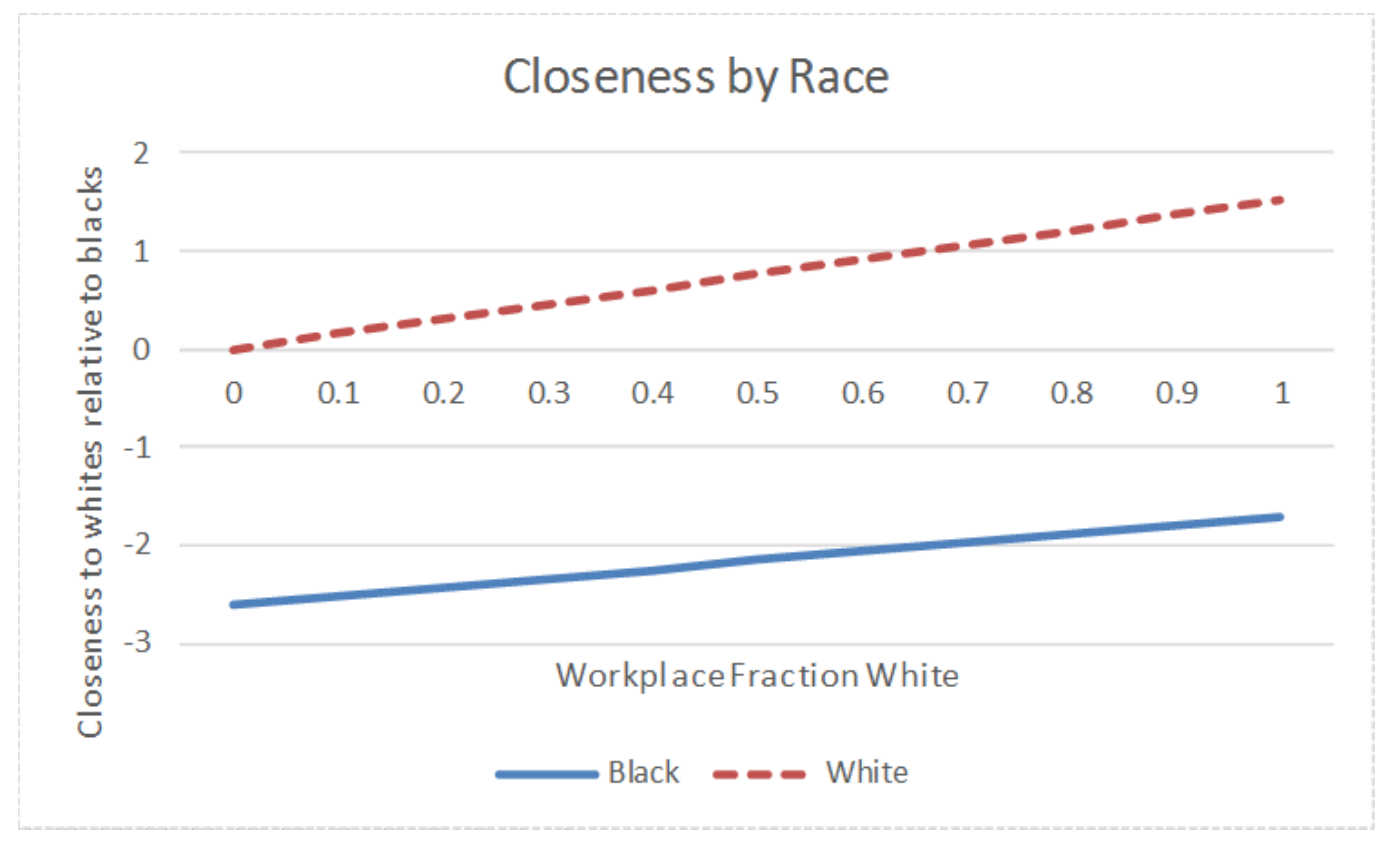

Figure 1: Relative Closeness to Whites over Workplace Fraction White

Notes: The dashed line represents the product of workplace fraction White and the coefficient estimate on workplace fraction White (i.e., 1.52) from a model of the closeness to Whites relative to Black closeness (Column 3 of Table 1). The solid line takes the value of the race coefficient at a zero percent White workplace, and then adds the product of the percent White in workplace times the sum of the level and the race interaction coefficients on percent White in workplace: -2.613+workplace fraction White*(1.52-0.606). 
Table 1: Relationship between workplace racial composition and responses to survey questions about race

\begin{tabular}{|c|c|c|c|c|c|}
\hline & $\begin{array}{c}\text { Closeness to Blacks }(1= \\
\text { not at all close to } \\
9=\text { very close })\end{array}$ & $\begin{array}{c}\text { Closeness to Whites } \\
\text { (1= not at all close to } \\
\text { 9=very close })\end{array}$ & $\begin{array}{l}\text { Difference between how } \\
\text { close to Whites and how } \\
\text { close to Blacks (- } \\
8=\text { much closer to } \\
\text { Blacks, } 8=\text { much closer } \\
\text { to Whites) }\end{array}$ & $\begin{array}{l}\text { Attitude toward gov't } \\
\text { help for Blacks ( } 1=\text { too } \\
\text { little, } 3=\text { too much) }\end{array}$ & $\begin{array}{c}\text { Opposed to interracial } \\
\text { marriage }\end{array}$ \\
\hline \multicolumn{6}{|c|}{ Summary Statistics } \\
\hline Black mean & 7.625 & 5.921 & -1.704 & 1.242 & .035 \\
\hline White mean & 5.439 & 6.997 & 1.558 & 1.991 & .091 \\
\hline \multicolumn{6}{|c|}{ Coefficient Estimates } \\
\hline Black & $\begin{array}{c}1.376^{* * *} \\
(0.198)\end{array}$ & $\begin{array}{c}-1.274 * * * \\
(0.206)\end{array}$ & $\begin{array}{c}-2.613^{* * *} \\
(0.235)\end{array}$ & $\begin{array}{c}-0.754 * * * \\
(0.054)\end{array}$ & $\begin{array}{l}-0.079 * \\
(0.033)\end{array}$ \\
\hline Workplace \% White & $\begin{array}{c}-1.226 * * * \\
(0.136)\end{array}$ & $\begin{array}{l}0.273 * \\
(0.127)\end{array}$ & $\begin{array}{c}1.520 * * * \\
(0.163)\end{array}$ & $\begin{array}{c}0.051 \\
(0.052)\end{array}$ & $\begin{array}{l}-0.042 \\
(0.031)\end{array}$ \\
\hline $\begin{array}{l}\text { Black*workplace \% } \\
\text { White }\end{array}$ & $\begin{array}{l}0.980 * * \\
(0.320) \\
\end{array}$ & $\begin{array}{r}0.438 \\
(0.320) \\
\end{array}$ & $\begin{array}{l}-0.606 \\
(0.383) \\
\end{array}$ & $\begin{array}{c}0.026 \\
(0.078) \\
\end{array}$ & $\begin{array}{c}0.025 \\
(0.046) \\
\end{array}$ \\
\hline $\mathrm{N}$ & 6,505 & 6,469 & 6,437 & 6,603 & 3,964 \\
\hline
\end{tabular}

Notes: Estimates based on Black and non-Hispanic White sample respondents to the General Social Survey (GSS) in relevant years. Each column represents a specific survey variable from the GSS except for the last column, which is based on the difference between the survey responses to the two preceding questions. The first panel presents sample means, and the second panel presents coefficient estimates where each column contains the results of a single regression. The regression model specification includes indicators for year of survey and for missing report of workplace \% White and its interaction with Black; heteroskedasticity-robust standard errors in parentheses. 
Table 2: Descriptive Statistics for the Establishment Sample

\begin{tabular}{lcc}
\hline \hline Variables & Mean & Standard Deviation \\
\hline Revenue minus Materials Cost & 5055.8 & 176398.3 \\
Non College Employment & 57641.8 & 213107 \\
College Employment & 17096.8 & 133139.6 \\
Equipment Capital (\$1,000s) & 1762.7 & 16149.4 \\
Structure Capital (\$1,000) & 632.6 & 8725.2 \\
Mean Tract FE & -0.0287 & 0.0931 \\
Employment Density & 0.3065 & 1.0318 \\
Own-Race Exposure Index & 0.5564 & 0.2073 \\
Share College & 0.2598 & 0.106 \\
Share College Own Race Exp Index & 0.574 & 0.2331 \\
Firm Percent Black & 0.0773 & 0.13 \\
Firm Percent Hispanic & 0.1859 & 0.2302 \\
Firm Percent Asian & 0.0836 & 0.1554 \\
Firm Percent Other Race & 0.0055 & 0.0326 \\
Single Establishment Firm & 0.8663 & 0.3404 \\
Zip Code Missing & 0.2284 & 0.4198 \\
Sample size & & 111,695 \\
\hline \hline
\end{tabular}

Notes: The table presents the means and standard deviations of establishment and local work area attributes for the large metropolitan area manufacturing establishment sample. 
Table 3: Total Factor Productivity Regressions with Controls for Local Work Area

\begin{tabular}{|c|c|c|c|c|}
\hline Variables & Translog model & $\begin{array}{c}\text { Translog Model with } \\
\text { Own Race Exposure } \\
\text { Indices }\end{array}$ & $\begin{array}{c}\text { Own Race Translog } \\
\text { Model with Mean } \\
\text { Tract FE }\end{array}$ & $\begin{array}{c}\text { Industry } \\
\text { Interactions and } \\
\text { PUMA FE }\end{array}$ \\
\hline Employment Density & $0.0288 * * *(16.68)$ & $-0.0012(-0.10)$ & $-0.0001(-0.00)$ & NA \\
\hline Density*Race Exposure Index & & $0.0919^{* *}(2.57)$ & $0.0913^{* * *}(2.94)$ & $0.1851^{* * *}(10.45)$ \\
\hline Share College & $0.2033^{* * *}(8.30)$ & $0.096(1.30)$ & $0.0253(0.34)$ & NA \\
\hline $\begin{array}{l}\text { Share College*Race College Exposure } \\
\text { Index }\end{array}$ & & 0.1779 (1.59) & $0.2115^{*}(1.91)$ & $0.4897^{* * *}(2.87)$ \\
\hline R Squared & 0.9086 & 0.9086 & 0.9088 & 0.9106 \\
\hline Sample Size & 111695 & 111695 & 111538 & 111538 \\
\hline \multicolumn{5}{|c|}{$\begin{array}{l}\text { Notes: Coefficient estimates of establishment revenue net of materials cost on a translog model of production where inputs are capital } \\
\text { equipment, capital structure, college educated labor and non-college educated labor. Each column presents estimates from a single } \\
\text { regression. Column } 1 \text { presents the baseline estimates with just the controls for density, share college, factor inputs and metropolitan area } \\
\text { and three-digit industry fixed effects. The next column adds controls for the same race exposure to workers and college educated workers } \\
\text { plus the interaction of these variables with employment density and share college, respectively. The third column expands the translog } \\
\text { production function to include the average unobserved quality based on the residential locations of workers in the establishment's zip code } \\
\text { by 3-digit industry cell and the tract FE estimates from the wage model. The fourth column adds the interaction of employment density and } \\
\text { share college with the three-digit industry dummies and PUMA fixed effects. College and non-college labor are based on total labor inputs } \\
\text { and the fraction of workers in the Census long form data in an establishment's zip code by 3-digit industry cell who have a four year college } \\
\text { degree. Employment density and share college are calculated for all manufacturing workers in the census long form sample working in the } \\
\text { establishment's PUMA excluding the workers in the establishment's zip code by 3-digit industry cell. The exposure indices are the average } \\
\text { exposure of all workers in the establishment's zip code by three-digit industry cell to manufacturing workers or college educated } \\
\text { manufacturing workers of the same race in the establishment's PUMA (omitting employment in the establishment's zip code). Establishment } \\
\text { net revenue is estimated for respondents of the } 1997 \text { Census of Manufacturers in metropolitan areas with populations over } 1 \text { million } \\
\text { residents. Heteroskedasticity-robust standard errors are clustered on PUMA of employment. T-statistics in parentheses. }\end{array}$} \\
\hline
\end{tabular}


Table 4: Exposure to Establishment TFP Gains from Agglomeration

\begin{tabular}{lccccc}
\hline \hline \multirow{2}{*}{ Worker Race } & \multicolumn{5}{l}{ Differential Establishment Average Worker Exposure to Own Race } \\
& \multicolumn{4}{l}{ Establishment Exposure } & \multicolumn{2}{c}{ Employment Density } & Racial Difference \\
& White & Minority & Sample Mean & Estimate & \\
\hline Black & 0.634 & 0.487 & 0.307 & 0.091 & 0.0041 \\
Hispanic & 0.634 & 0.407 & 0.307 & 0.091 & 0.0063 \\
Asian & 0.634 & 0.406 & 0.307 & 0.091 & 0.0064 \\
\hline \multicolumn{5}{l}{ Worker Race } & Differential Establishment Average College Educated Worker Exposure to Own Race \\
\hline Black & Establishment Exposure & \multicolumn{3}{c}{ Share College } & Racial Difference \\
Hispanic & White & Minority & Sample Mean & Estimate & \\
Asian & 0.665 & 0.499 & 0.260 & 0.212 & 0.0091 \\
\hline \hline
\end{tabular}

Notes: Panel 1 presents differences based on firm TFP returns from employment density, and Panel 2 presents differences based on returns from share college in surrounding area. Column 1 present the average exposure of White workers to their establishments' workers average exposure to own race workers in the surrounding PUMA, and column 2 presents the average exposure for minority workers. Column 3 presents the sample mean employment density or share college exposure for establishments, and column 4 presents the estimated effects of establishment same race exposure on returns to density and share college from column 3 Table 3 . The final column presents the result of differencing minority exposure from White exposure multiplying by the sample mean for employment density or share college and then multiplying by the effect estimate. 
Table 5: Total Factor Productivity Regressions by Industry Patent Levels

\begin{tabular}{|c|c|c|c|c|c|}
\hline Variables & $\begin{array}{c}\text { Own Race Translog } \\
\text { Model with Mean } \\
\text { Tract FE }\end{array}$ & $\begin{array}{c}\text { Industry Patent } \\
\text { Activity Above } \\
\text { Median }\end{array}$ & $\begin{array}{l}\text { Industry Patent } \\
\text { Activity Below } \\
\text { Median } \\
\end{array}$ & $\begin{array}{c}\text { Industry R\&D } \\
\text { Activity Above } \\
\text { Median }\end{array}$ & $\begin{array}{c}\text { Industry R\&D } \\
\text { Activity Below } \\
\text { Median } \\
\end{array}$ \\
\hline Density*Race Exposure Index & $0.0913^{* * *}(2.94)$ & $0.0952^{* *}(2.24)$ & $0.2049^{* * *}(6.24)$ & $0.1609^{* * *}(4.10)$ & $0.1611^{* * *}(4.10)$ \\
\hline $\begin{array}{l}\text { Share College*Race College Ex } \\
\text { Index }\end{array}$ & $0.2115^{*}(1.91)$ & $0.7358^{* * *}(3.04)$ & $0.0039(0.02)$ & $0.7386^{* * *}(2.92)$ & $0.0551(0.27)$ \\
\hline R Squared & 0.9106 & 0.9049 & 0.9162 & 0.908 & 0.9125 \\
\hline Sample Size & 111538 & 65412 & 46126 & 61194 & 50344 \\
\hline
\end{tabular}

Notes: Coefficients estimates of establishment revenue net of materials cost on a translog model of production where inputs are capital equipment,

capital structure, college educated labor and non-college educated labor. Each column presents estimates from a single regression. Column 1 presents the estimates with controls for unobserved worker quality in the translog production function, plus density, share college, factor inputs and metropolitan area and three-digit industry fixed effects. The next four columns present estimates for this specification estimated separately for samples in three-digit industries with above and below median levels of patent activity and above and below median levels of R\&D activity. College and non-college labor are based on total labor inputs and the fraction of workers in the Census long form data in an establishment's zip code by 3-digit industry cell who have a four year college degree. Employment density and share college are calculated for all manufacturing workers in the census long form sample working in the establishment's PUMA excluding the workers in the establishment's zip code by 3-digit industry cell. The exposure indices are the average exposure of all workers in the establishment's zip code by three-digit industry cell to manufacturing workers or college educated manufacturing workers of the same race in the establishment's PUMA (omitting employment in the establishment's zip code). Establishment net revenue is estimated for respondents of the 1997 Census of Manufacturers in metropolitan areas with populations over 1 million residents. Heteroskedasticity-robust standard errors are clustered on PUMA of employment. T-statistics in parentheses. 
Table A1: Total Factor Productivity Regressions with Controls for Local Work Area

\begin{tabular}{|c|c|c|c|}
\hline Variables & Translog model & $\begin{array}{l}\text { Translog Model with } \\
\text { Own Race Exposure } \\
\text { Indices }\end{array}$ & $\begin{array}{c}\text { Own Race Translog } \\
\text { Model with Mean } \\
\text { Tract FE }\end{array}$ \\
\hline Non College Employment & $0.3502 * * *(21.07)$ & $0.3515^{* * *}(21.37)$ & $0.3461 * * *(21.22)$ \\
\hline Non College Employment Squared & $0.0512 * * *(71.91)$ & $0.0515^{* * *}(76.59)$ & $0.0523^{* * *}(80.49)$ \\
\hline College Employment & $0.0695 * * *(13.57)$ & $0.0679 * * *(13.15)$ & $0.0745^{* * *}(15.02)$ \\
\hline College Employment Squared & $0.0169 * * *(35.96)$ & $0.0166^{* * *}(37.01)$ & $0.0159^{* * *}(37.17)$ \\
\hline Equipment Capital & $0.4729^{* * *}(27.42)$ & $0.4743^{* * *}(27.55)$ & $0.4842^{* * *}(29.21)$ \\
\hline Equipment Capital Squared & $0.0217 * * *(22.11)$ & $0.0218^{* * *}(22.11)$ & $0.0215^{* * *}(22.06)$ \\
\hline Structure Capital & $0.0872^{* * *}(21.37)$ & $0.0869 * * *(21.27)$ & $0.0872 * * *(21.44)$ \\
\hline Structure Capital Squared & $0.0022 * * *(6.20)$ & $0.0022 * * *(6.19)$ & $0.0023 * * *(6.35)$ \\
\hline Mean Tract FE & & & $-1.0220 * * *(-4.58)$ \\
\hline Mean Tract FE Squared & & & $0.2806 * *(2.09)$ \\
\hline Equipment Capital*Non College Employment & $-0.0600 * * *(-34.96)$ & $-0.0604 * * *(-36.30)$ & $-0.0607 * * *(-35.94)$ \\
\hline Equipment Capital*College Employment & $-0.0111^{* * *}(-14.76)$ & $-0.0109 * * *(-14.45)$ & $-0.0110 * * *(-14.85)$ \\
\hline Structure Capital*Non College Employment & $-0.0027 * * *(-4.47)$ & $-0.0027 * * *(-4.48)$ & $-0.0027 * * *(-4.46)$ \\
\hline Structure Capital*College Employment & $-0.0014 * * *(-6.38)$ & $-0.0014 * * *(-6.39)$ & $-0.0014 * * *(-6.16)$ \\
\hline Equipment Capital*Structure Capital & $-0.0053^{* * *}(-8.22)$ & $-0.0053^{* * *}(-8.13)$ & $-0.0054 * * *(-8.22)$ \\
\hline Non College Employment*College Employment & $-0.0034 * * *(-4.30)$ & $-0.0033^{* * *}(-4.16)$ & $-0.0031^{* * *}(-3.95)$ \\
\hline Employment Density & $0.0288 * * *(16.68)$ & $-0.0012(-0.10)$ & $-0.0001(-0.00)$ \\
\hline Own-Race Exposure Index & & $-0.065(-0.70)$ & $-0.0567(-0.63)$ \\
\hline Density*Race Exposure Index & & $0.0919^{* *}(2.57)$ & $0.0913^{* * *}(2.94)$ \\
\hline Share College & $0.2033^{* * *}(8.30)$ & $0.096(1.30)$ & $0.0253(0.34)$ \\
\hline Share College Own Race Exp Index & & $0.0534(0.42)$ & $0.0236(0.20)$ \\
\hline Share College*Coll Race Exp Index & & $0.1779(1.59)$ & $0.2115^{*}(1.91)$ \\
\hline Mean Tract FE*Equipment Capital & & & $0.0314(0.92)$ \\
\hline Mean Tract FE*Structure Capital & & & $-0.0030(-0.42)$ \\
\hline Mean Tract FE*Non College Employment & & & $0.0722 * * *(2.66)$ \\
\hline Mean Tract FE*College Employment & & & $0.0389 * * *(5.18)$ \\
\hline Firm Percent Black & & $-0.0377(0.93)$ & $-0.0311(0.79)$ \\
\hline Firm Percent Hispanic & & $-0.08473 * *(2.06)$ & $-0.07597 *(1.92)$ \\
\hline Firm Percent Asian & & $-0.07857 * *(2.04)$ & $-0.06999 *(1.89)$ \\
\hline Firm Percent Other Race & & $-0.0981(1.57)$ & $-0.0914(1.46)$ \\
\hline Guryan controls for emp den & $-0.5166(-0.02)$ & $-3.8784(-0.12)$ & $-4.6216(-0.16)$ \\
\hline Guryan controls for college share & $-6.2514 * *(-2.19)$ & $-5.8335^{* *}(-1.97)$ & $-5.3116 *(-1.82)$ \\
\hline \multicolumn{2}{|l|}{ Guryan controls for emp den*Race Exposure Index } & $2.7116 *(1.77)$ & 2.1239(1.43) \\
\hline \multicolumn{2}{|c|}{ Guryan controls for college share*Coll Race Exposure Index } & $-0.3994(-1.62)$ & $-0.3420(-1.50)$ \\
\hline R Squared & 0.9086 & 0.9086 & 0.9088 \\
\hline Sample size & 111695 & 111695 & 111538 \\
\hline
\end{tabular}


Notes: Coefficients estimates of firm revenue net of materials cost on a translog model of production where inputs are capital equipment, capital structure, college educated labor and non-college educated labor plus for the last column average unobserved quality based on the worker residential locations and the tract FE estimates from the wage model. Each column contains estimates for a single regression, and these regressions are the same as the regressions presented in the first three columns of Table 2. The regression model is estimated for respondents of the 1997 Census of Manufacturers for in the metropolitan areas with populations over 1 million residents. The regression also includes metropolitan area and three-digit industry fixed effects. Heteroskedasticity-robust standard errors are clustered on PUMA of employment. T-statistics in parentheses. 